\title{
Age-size relationship at reproduction of South African female loggerhead turtles Caretta caretta
}

\author{
Jenny Tucek ${ }^{1, *}$, Ronel Nel ${ }^{1}$, Marc Girondot ${ }^{2}$, George Hughes ${ }^{3}$ \\ ${ }^{1}$ Nelson Mandela Metropolitan University, Department of Zoology, Port Elizabeth 6031, South Africa \\ ${ }^{2}$ Laboratoire Écologie, Systématique et Évolution (UMR8079), Faculté des Sciences d'Orsay, Université Paris-Sud, \\ 91405 Orsay, France \\ ${ }^{3} 183$ Amber Valley, Private Bag X 30, Howick 3290, South Africa
}

\begin{abstract}
Average age and size at first reproduction are important demographic parameters used in the management and conservation of populations. For sea turtles, absolute values for these parameters are still ambiguous, as most species are slow-growing, late-maturing migrants which are rarely encountered during the first 1 to 2 decades of their lives. Additionally, growth is significantly influenced by a variety of intrinsic and extrinsic factors which make it difficult to describe age-size relationships. Extensive notching (mutilation-tagging) of South African loggerhead turtles was used to determine age and size at reproduction (putative first nesting season), and thus to identify the trigger for sexual maturation. To date, 137 clearly identified notched adult females have been encountered at the nesting beach. A Gaussian and log-normal distribution were fitted to the age distribution data but only the Gaussian distribution can be used to safely estimate age at first observation, as the right part ('older ages') of the distribution is still unknown. The estimated age at first observation was corrected for the possibility that a female was not encountered during her first nesting season. Results indicate an average age of $36.2 \pm$ SD $7.71 \mathrm{yr}$ (95\% CI 28.2 to $44.3 \mathrm{yr}$ ) with a straight carapace length $\left(\mathrm{SCL}_{\min }\right)$ of $83.7 \pm 4.15 \mathrm{~cm}(95 \% \mathrm{CI} 83.0$ to $84.4 \mathrm{~cm})$. It was concluded that size is a more important threshold for the initiation of the maturation process than age and that the onset of sexual maturity is dependent on intrinsic and extrinsic factors.
\end{abstract}

KEY WORDS: Age and size at reproduction $\cdot$ Loggerhead turtle $\cdot$ Mutilation tagging

\section{INTRODUCTION}

Age and size at first reproduction, reproductive lifespan, and the number and size of offspring produced per individual are fundamental life history characteristics required to model population dynamics or productivity. They are frequently used in conservation to model the likelihood of a population going extinct or in wild stocks to estimate the off-take (Scott et al. 2012), e.g. for setting fishing quotas. Life history characteristics are easy to track in captive animals but this is much more difficult in wild populations (Scott et al. 2012), especially those of wideranging or migratory species. Due to the range of factors affecting individuals/populations it is also difficult to predict/model these parameters.
The innate life history characteristics of a species/ population are highly modified by energy availability (Berner \& Blanckenhorn 2007). Therefore, food accessibility and the rate at which an organism can process food (West et al. 2004, Molles 2010) regulate the metabolic investment of energy into reproduction or growth. Thus, the onset of sexual maturity - as indicated by a reduction in energy investment into somatic growth and a greater energy allocation into the growth and maturation of reproductive organs (Hatase et al. 2004, Berner \& Blanckenhorn 2007, Snover et al. 2007, Bjorndal et al. 2012) — is dependent on both population characteristics (intrinsic) and the environment (extrinsic).

For sea turtles, growth rates, and thereby age and size at sexual maturity, are influenced by intrinsic and 
extrinsic factors. Intrinsic factors that affect the growth rate in sea turtles include species, genotype, health status and sex (Chaloupka \& Limpus 1997, Van Dam 1999, Heppell et al. 2003). Extrinsic factors that regulate growth rate are, for example, water temperature, food quality and food availability (Parker 1929, Bjorndal et al. 2003, Balazs \& Chaloupka 2004). These factors are easy to regulate in captive studies but are often highly variable and difficult to measure under natural conditions (Mendonca 1981) as sea turtles migrate over thousands of kilometres and experience large habitat variations that additionally affect their growth rate (Musick \& Limpus 1997, Casale et al. 2007, Koch et al. 2007). The variability in growth rate has already been documented in different species and several populations. Green turtles from the Hawaiian archipelago (Balazs \& Chaloupka 2004) and the southern Great Barrier Reef (Chaloupka et al. 2004) grow at different rates due to differences in food quality and availability, as well as in sea surface temperatures of their foraging grounds. Furthermore, Hughes (1974) and Bjorndal et al. (2003) found that compensatory growth (accelerated growth) appears in juvenile sea turtles when they move from a suboptimal environment to better conditions. Similarly, different sexes can follow different growth patterns, as shown for green (Chaloupka et al. 2004) and hawksbill (Chaloupka \& Limpus 1997) turtles on the Great Barrier Reef. Here immature female green turtles grow significantly faster than males after a juvenile growth spurt, resulting in sexual dimorphism in adult size (Limpus \& Chaloupka 1997). Immature hawksbill females grow faster than males at all recorded sizes (Chaloupka \& Limpus 1997). Although variability in growth rate in natural populations has been documented, the link between age and size at sexual maturity remains unidentified. Size per se is thus not a reliable indicator of age in turtles, but a minimum size has to be reached before reproduction can take place (Hughes 1974).

Current methods used to estimate the growth rate of individuals in sea turtle populations require substantial investment in in-water studies (e.g. on the feeding ground). The most common field methods include capture-mark-recapture techniques (Frazer \& Ehrhart 1985, Limpus \& Chaloupka 1997, Bresette \& Gorham 2001, Seminoff et al. 2002, Casale et al. 2009b) and length-frequency analysis (Bjorndal et al. 2001, Casale et al. 2009a). However, these methods do not provide a definitive measure of age at maturity, but rather an estimate of growth. Estimating age and size at first reproduction in wild sea turtle populations requires a permanent mark, which can be applied to the hatchling and which grows with the turtle throughout its life. Mutilation tagging, i.e. living tags (Bell \& Parsons 2002), notching of hatchlings with a year-code (Hughes \& Brent 1972) or DNA sampling (Dutton et al. 2005) allow the definitive determination of age and size at first reproduction. L. Guastella and G. Hughes (unpubl. data) later confirmed the validity of notch codes, as they established that notching has no harmful effect on a turtle's health (as indicated through growth and mortality rates). However, mutilation tagging is labour intensive (Bjorndal et al. 2001) as it requires notching large numbers of individuals to compensate for high annual mortality (Table 1). Moreover, it takes many years to produce results as surviving individuals are expected to return only decades later. To date, results

Table 1. Summary of the South African notching data, showing numbers of loggerhead turtle hatchlings notched per season and the number of notched females subsequently observed from each year of notching. The numbers of notched hatchlings were extracted from annual season reports by the Natal Parks Board (1972-1998) and Ezemvelo KZN Wildlife (1999-2002)

\begin{tabular}{|c|c|c|}
\hline Season & $\begin{array}{l}\text { Hatchlings } \\
\text { notched }\end{array}$ & $\begin{array}{c}\text { Notched } \\
\text { females observed }\end{array}$ \\
\hline 1972 & 5000 & 6 \\
\hline 1973 & 10250 & 7 \\
\hline 1974 & 12133 & 22 \\
\hline 1975 & 11267 & 13 \\
\hline 1976 & 14720 & 18 \\
\hline 1977 & 13463 & 24 \\
\hline 1978 & 15130 & - \\
\hline 1979 & 15981 & 1 \\
\hline 1980 & 8489 & - \\
\hline 1981 & 7507 & 2 \\
\hline 1982 & 5634 & - \\
\hline 1983 & 7383 & - \\
\hline 1984 & 7585 & 3 \\
\hline 1985 & 9712 & - \\
\hline 1986 & 3784 & 1 \\
\hline 1987 & 18038 & 3 \\
\hline 1988 & 11380 & 5 \\
\hline 1989 & 9071 & 2 \\
\hline 1990 & 5189 & 16 \\
\hline 1991 & 9406 & 3 \\
\hline 1992 & 12521 & - \\
\hline 1993 & 18046 & 6 \\
\hline 1994 & 12068 & 1 \\
\hline 1995 & 12856 & 2 \\
\hline 1996 & 12203 & 1 \\
\hline 1997 & 10038 & 1 \\
\hline 1998 & 14981 & - \\
\hline 1999 & 9028 & - \\
\hline 2000 & 12424 & - \\
\hline 2001 & 9928 & - \\
\hline 2002 & 7596 & - \\
\hline
\end{tabular}


are only known from 2 mutilation tagging studies: the Ezemvelo KZN Wildlife (previously known as Natal Parks Board) notching programme in South Africa and the study carried out by Queensland's Environmental Protection Agency in Australia. The notching programme in South Africa started $40 \mathrm{yr}$ ago and Baldwin et al. (2003) estimated an arithmetic mean age at first nesting of $19.5 \mathrm{yr}$ (range 10 to $29 \mathrm{yr}$ ), based on a limited sample size and not taking into account that the sample was time-censored. The notching programme in Australia, which was conducted from 1976 to 1983 with 129921 loggerhead hatchlings notched (Limpus et al. 1994), on the other hand, had very few returns; these suggested a minimum age at first nesting of around 29 yr (Limpus 2008). The present study aims to re-assess the average age and size during the putative first nesting season of loggerhead females nesting in South Africa through the evaluation of notch codes (mutilation tagging), as well as to determine whether size or age is the principal driver of sexual maturity.

\section{MATERIALS AND METHODS}

The South African nesting beach is situated within the iSimangaliso Wetland Park, at the southern end of the tropics $\left(27^{\circ} \mathrm{S}\right)$ in the north-eastern coastal province of KwaZulu-Natal (KZN) (Fig. 1). Between the 1972 and 2002 hatching seasons (which last from January to March with a peak in February) about 320000 loggerhead hatchlings were notched by clipping out marginal scales with a leather punch, applying a unique seasonal code (Hughes 2002, Baldwin et al. 2003). Single notch codes were used during the first years, but were replaced with a double-notch procedure 8 yr into the programme, to avoid possible confusion caused by a turtle coming ashore with an injury representing a single notch. The nesting data obtained from returning females in the beach monitoring programme are standard to most nest monitoring programmes and included: species, flipper and passive integrated transponder (PIT) tag numbers, carapace size and nest position along the beach, as well as the notching code. Thereby, carapace length was measured from the anterior point at midline to the posterior notch at midline $\left(\mathrm{SCL}_{\min }\right)$ and width (SCW) at the widest point (after Hughes et al. 1967 and Bolten 1999). The age of a notched female on its first encounter on the nesting beach is hereafter referred to as 'age at first observation' as it was assumed that not all females are encountered during their first nesting season (Thorson et al. 2012, Nel et

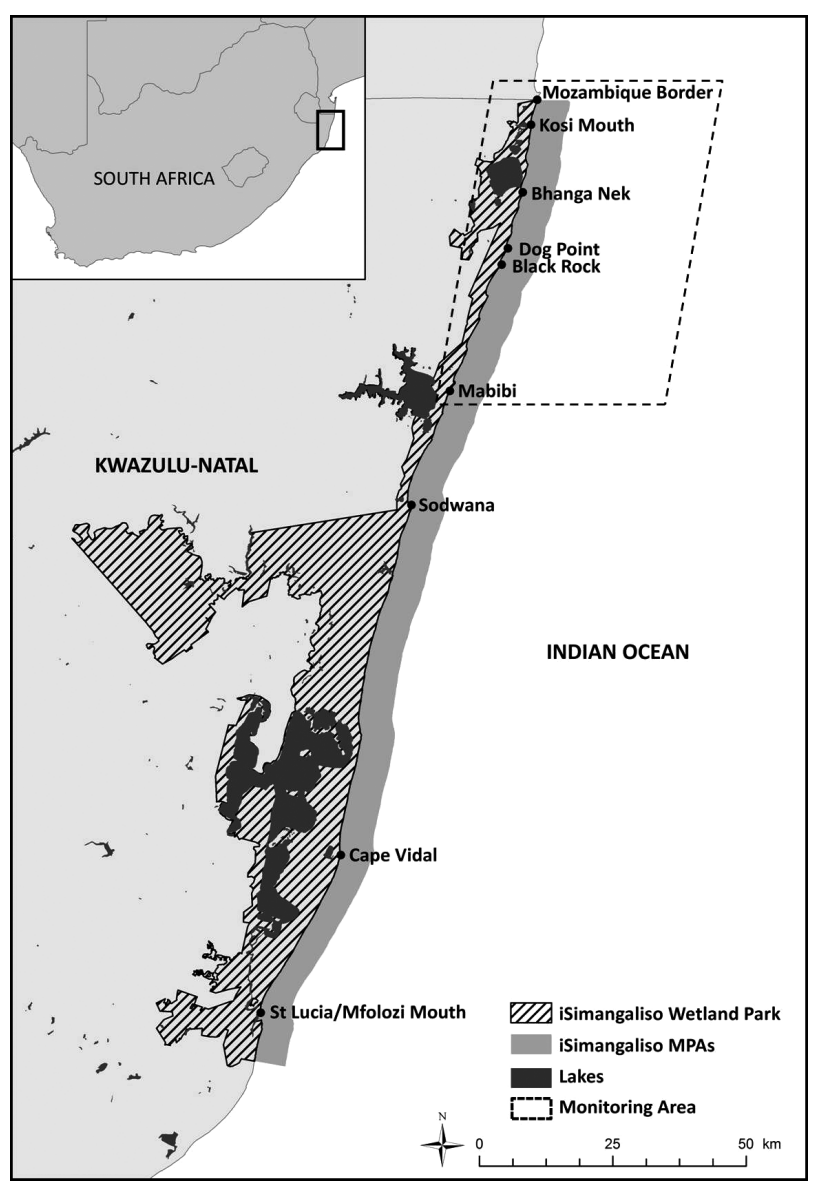

Fig. 1. The iSimangaliso Wetland Park, South Africa, including the extent of the Marine Protected Area (MPA), extending to 3 nautical miles from the coast, and the monitoring area south of the Mozambique border

al. 2013). Additionally, individuals with unclear or contradictory notch codes were removed from the sample. Further, the age of a notched female was calculated under the assumption that the turtle had hatched on 1 February (peak hatching) of its cohort. If an adult female was encountered more than once during its observed first nesting season its mean size for that season was used to reduce measuring error.

A Shapiro-Wilk test was used to confirm normality for the size distribution of notched females at first observation. A Generalised Linear Model (GLM) was applied to identify significant factors influencing size at first observation. The factors tested were age, year of notching and the number of notches (single or double notched). A Gaussian identity link based on the result of the Shapiro-Wilk normality test was employed. The significance of co-factors was assessed by an analysis of deviance using chi-square statistics. All interactions were investigated, and backward selection was used to simplify the model. 
In contrast to the size of notched individuals, the distribution of age at first observation is biased; the distribution is naturally truncated because the highest (or oldest) age classes have not yet been observed (Fig. 2). To take into account the truncated nature of the age distribution, the parameters providing the best explanation for the age distribution were identified using the maximum likelihood method (Gupta 1973). As the full distribution of 'age at first observation' is not known, both Gaussian and log-normal distributions were tested. Let $D(\mu, \sigma)$ be the age distribution at first observation ( $D$ being Gaussian or log-normal) and $y$ the time period since an individual was notched. The likelihood $L$ of observing a female during its first nesting season at an age $x=A$ :

$$
\begin{gathered}
L[y, A, D(\mu, \sigma)] \# \operatorname{Pr}[x=A \mid D(\mu, \sigma)] / \\
\operatorname{Pr}[x<y \mid D(\mu, \sigma)]
\end{gathered}
$$

Both Gaussian and log-normal distributions were fitted and their respective likelihoods were compared through Akaike Information Criteria (AIC) and Akaike weight (Burnham \& Anderson 2002). The standard error of each parameter was estimated using the square root of the inverse of the Fisher information matrix at the point of maximum likelihood. R version 2.15.2 software (R Core Team 2012) was used for all of the statistical analysis. To correct for the possibility of missing the first nesting season of a female, the total number of nests per season (within the monitoring area) was divided by 3.7 (average nesting frequency for loggerheads after Nel et al. 2013) to estimate the number of nesting females. The probability

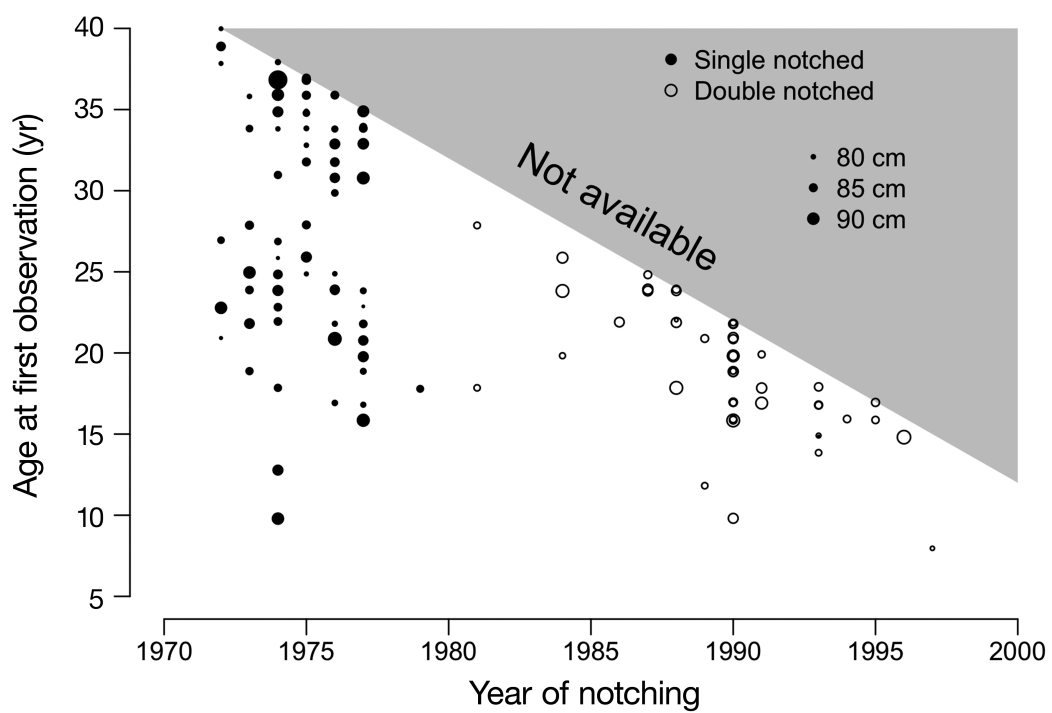

Fig. 2. Observed female loggerhead turtles $(n=137)$ notched between 1972 and 1997, showing age and size during their putative first nesting season in South Africa (see Table 1). Dot diameter indicates size, i.e. straight carapace length $\left(\mathrm{SCL}_{\min }\right)$ of encountering a nesting female at least once in a season is thus the number of recorded nesting individuals (identified through flipper or PIT tags) divided by the estimated number of females on the nesting beach. As this probability is constant over time, the average over $4 \mathrm{yr}$ (2008-2011), referred to as $\mathrm{p}_{\text {ind, }}$ was used. When a female nested in year $Y$, it was seen with a probability of $p_{\text {ind }}$ and not seen with a probability of $1-p_{\text {ind }}$. If not seen this year, it could be seen each subsequent nesting season, always with a probability of $\mathrm{p}_{\text {ind, }}$ and not seen with a probability of $1-\mathrm{p}_{\text {ind }}$. Thus the probability that a female which first nested in year $Y$ was first observed in year $Y+a$ is:

$$
\mathrm{p}_{a}=\left(1-\mathrm{p}_{\text {ind }}\right)^{a} \times \mathrm{p}_{\text {ind }}
$$

The mean observed age at first observation $A_{\text {obs }}$ has thus been corrected using these $\mathrm{p}_{a}$ to obtain an estimate of age at first nesting:

$$
\begin{gathered}
A_{\text {nest }}=A_{\text {obs }} \times \mathrm{p}_{0}+\left(A_{\text {obs }}-1\right) \times \\
\mathrm{p}_{1}+\ldots+\left(A_{\text {obs }}-\mathrm{n}\right) \times \mathrm{p}_{\mathrm{n}}
\end{gathered}
$$

\section{RESULTS}

The size-frequency distribution of females at first observation was normal (Shapiro-Wilk normality test, $W=0.99, \mathrm{p}=0.381)$ or log-normally distributed $(W=$ $0.99, \mathrm{p}=0.560)$. Female size at first nesting $(\mathrm{n}=137)$ was investigated with regards to age, year of notching and single or double notch code. No significant effect of any of these parameters was found (all $\mathrm{p}>$ 0.1 ; Fig. 3). The mean $\pm \mathrm{SD}$ size $\left(\mathrm{SCL}_{\min }\right)$ at first observation of loggerhead females nesting in South Africa was $83.7 \pm 4.15 \mathrm{~cm}$ (95\% CI 83.0 to $84.4 \mathrm{~cm}$, range 72.0 to $99.2 \mathrm{~cm}$, median $83.5 \mathrm{~cm}$ ).

The age distribution of notched females that returned each year is displayed in Fig. 4. This also includes the truncated Gaussian distribution. The fit of the truncated Gaussian distribution estimated a mean \pm SD age of $37.5 \pm$ $10.31 \mathrm{yr}$ for loggerhead turtles at their first observation (age 95\% CI $=29.3$ to $45.8 \mathrm{yr}$; SD $95 \% \mathrm{CI}=7.45$ to 13.17 ; $-\ln$ $L=391.37$; AIC 786.7397). The truncated log-normal distribution estimated a mean $\pm \mathrm{SD}$ age of $134.7 \pm 2.04 \mathrm{yr}$ at first observation (age 95\% CI = 11.8 to $1541.8 \mathrm{yr}$ SD $95 \% \mathrm{CI}=1.29$ to $3.22 ;-\ln$ $L=387.12$; AIC 778.2328). The log-normal distribution was selected against the Gaussian distribution as describing 
age at first observation better $(\mathrm{p}>0.9859)$. However, when both distributions are superimposed on the truncated area (Fig. 5), it is obvious that data are only available for the left side of the distribution. The right side of the distribution is only known for the Gaussian distribution, based on the symmetry of the model. The log-normal distribution is much less constrained than the Gaussian distribution but the right side of the distribution is unknown. Thus, only the Gaussian distribution can be used to estimate age at first observation. If we assume that some notched females were not encountered during their first nesting season but had nested previously, then the 'real' age at first reproduction for South African loggerhead turtles can be estimated as $36.2 \pm 7.71 \mathrm{yr}(95 \%$ CI 28.2 to $44.3 \mathrm{yr}$, range 8.0 to $40.0 \mathrm{yr}$; Table 2 ).

\section{DISCUSSION}

The age and size of putative neophyte nesters were determined through mutilation tagging and the results used to identify whether size or age drives sexual maturity. Over a $30 \mathrm{yr}$ period about 320000 hatchlings were marked, of which only 137 notched females were encountered at the natal nesting beach. This low recovery rate (Table 1) could be due to variable numbers of notched hatchlings, high natural or induced mortality (extrinsic factors), unclear notch codes that were discarded from the analysis, (male-)biased sex ratios of notched hatchlings and/or the fact that a large number of turtles have not yet

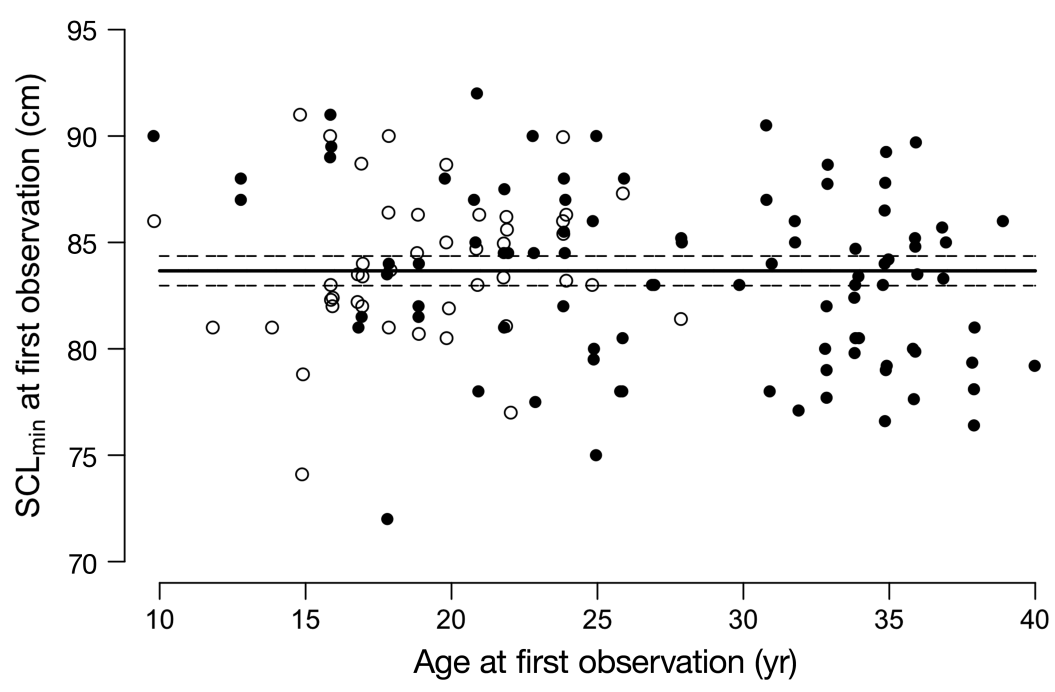

Fig. 3. Age and size distribution of single-notched $(\bullet)$ and double-notched (o) loggerhead females $(n=137)$ at first observation at the nesting beach in South Africa. $\mathrm{SCL}_{\min }$ : straight carapace length. The regression line indicates that no age-size relationship exists; dashed lines indicate $95 \%$ CI matured and will only return over the next 2 to 3 decades. Thus, simply calculating the mean age would present a false outcome, as all samples are timecensored, i.e. 'oldest age classes' are not observed yet.

When including the possibility that a female loggerhead was not encountered during her first nesting season, the mean age at reproduction (putative first nesting season) for the South African population was estimated at $36.2 \pm \mathrm{SD} 7.71 \mathrm{yr}$. This is much higher than reported for most other loggerhead populations (Table 3), but it is in agreement with the recovery profile of the South African population. The South African conservation and monitoring programme was initiated in 1963 and about 40 yr later the loggerhead population displays almost exponential population growth (Nel et al. 2013). This indicates that the elimination of poaching along the nesting beach has resulted in an increased reproductive success leading to population growth.

Mean size $\left(\mathrm{SCL}_{\min }\right)$ at first observation was $83.7 \pm \mathrm{SD}$ $4.15 \mathrm{~cm}$. This was not corrected for the possibility that the female could have nested in a previous season, as growth after first reproduction is negligible (Limpus \& Chaloupka 1997). South African loggerheads are similar in size to those from the south-eastern USA, but larger than those from the Mediterranean and smaller than the Australian populations (Table 3). Discrepancies in age and size at reproduction within and between populations (of the same species) could be based on intrinsic and/or extrinsic factors, or different methodologies (see Casale et al. 2009b, 2011a,b, Piovano et al. 2011 in Table 3). In the former case, South Africa's unique position between the warm Indian Ocean and the cold South Atlantic Ocean could have increased age and size ranges at first observation as hatchlings may grow up in a variety of environments.

The available age-size data at first observation of 137 loggerhead females indicated that neither age, year of notching nor notch code (single or double) affect female size at reproduction and thus no age-size relationship exists (Fig. 3). It is concluded that the maturation process of the reproductive organs, as well as the onset of reproduction itself, are correlated with a minimum size of the female (Hughes 1974), which may be reached at any given age dependent on intrinsic and extrinsic factors (Fig. 3). Similar results were found by Bjorndal et al. (2012) 
$\left.\begin{array}{l}3 \\ - \\ 0\end{array}\right]$

7
$\exists$
手

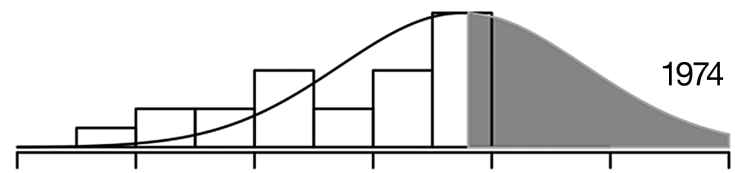

7
$\exists$
录
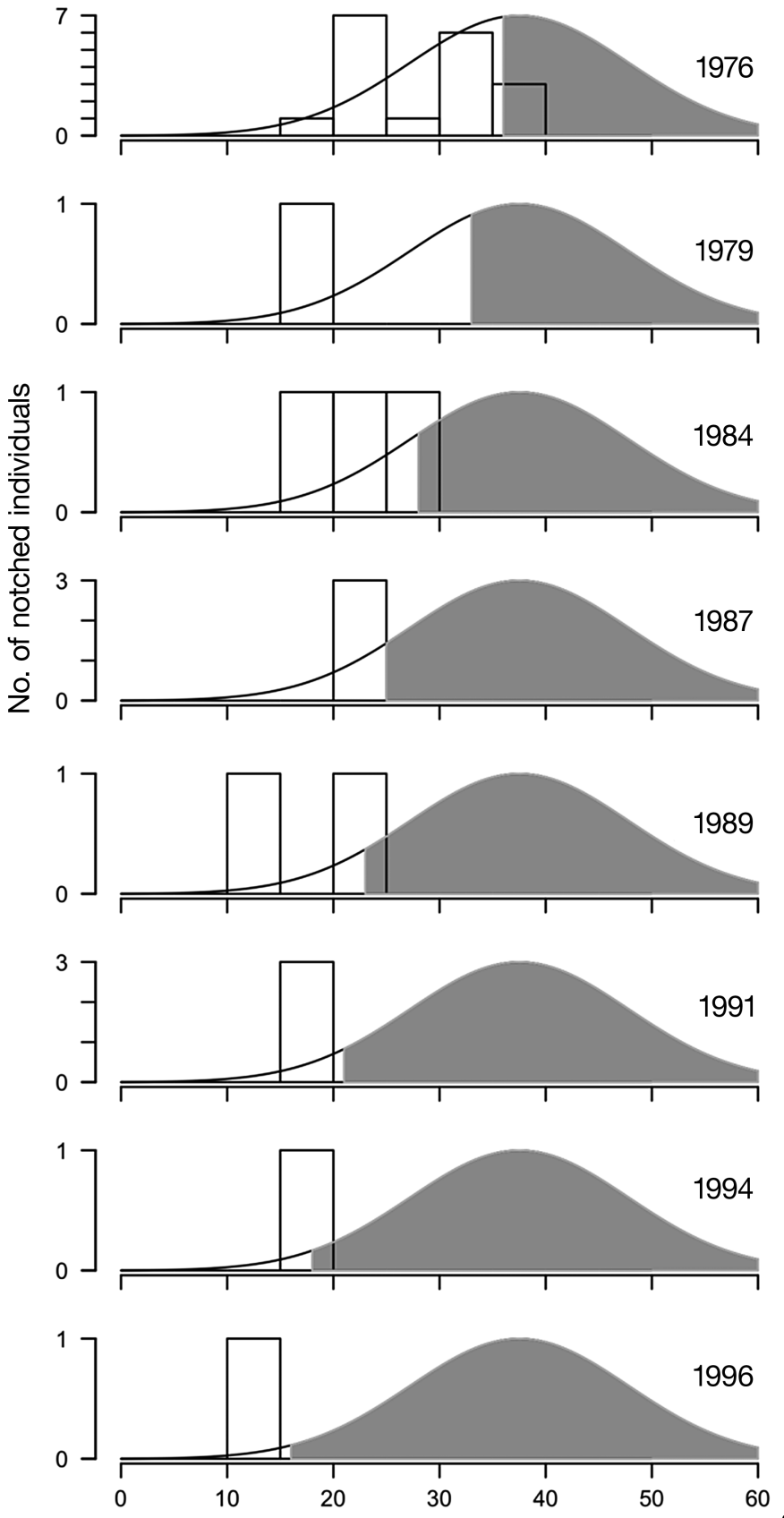

Age $(y)$
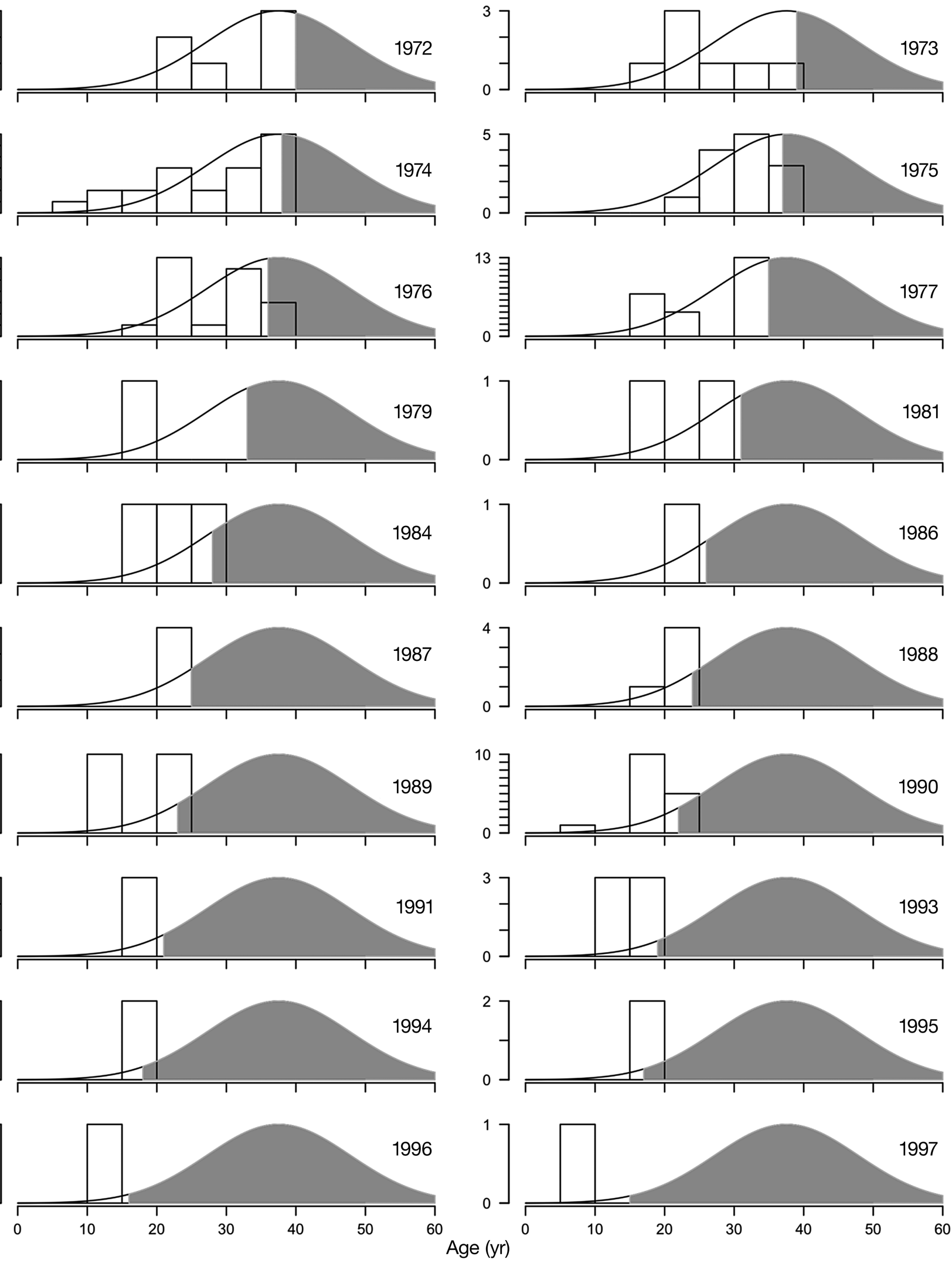

Fig. 4. Histograms of age at first observation of notched female loggerhead turtles, for each cohort. The curve shows the density of the fitted truncated Gaussian model. The shaded area indicates the lack of data for each distribution 


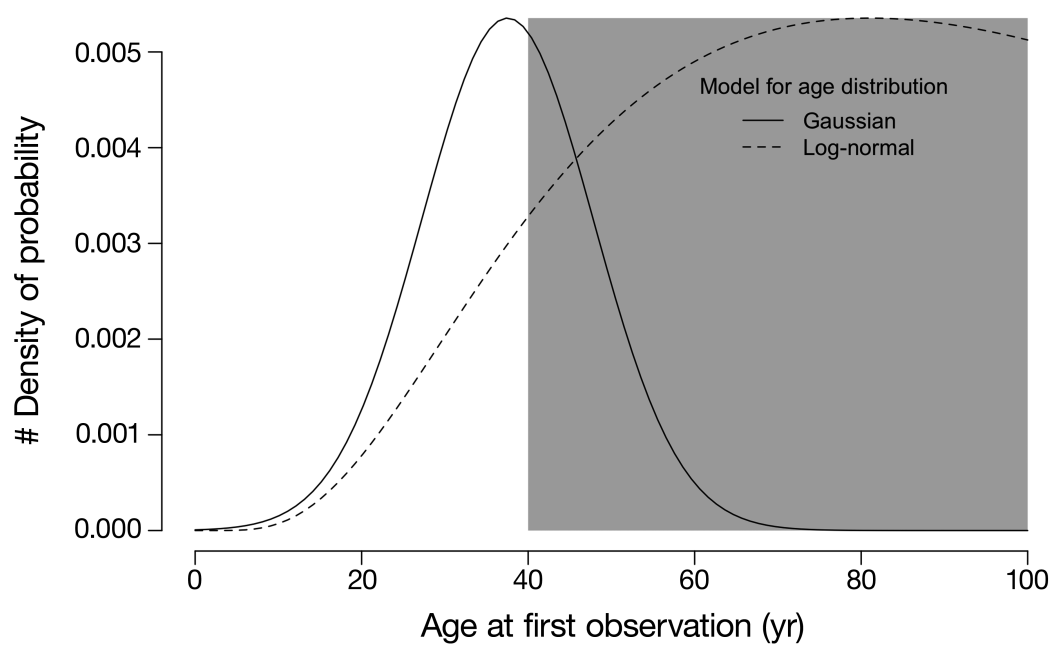

Fig. 5. Gaussian and log-normal distributions of age at first observation of female loggerhead turtles nesting in South Africa. The shaded area indicates the lack of data

Table 2. Estimated age (yr) of notched loggerhead females at first observation on the South African nesting ground $(\mathrm{n}=137)$. The second row corrects for the possibility that a notched female was not observed during its first nesting season and hence indicates the real age at first reproduction

\begin{tabular}{|lcccccc|}
\hline & \multicolumn{3}{c}{ Observed values } & \multicolumn{2}{c|}{ Age from Gaussian model } \\
& Min. & Mean & Max. & Min. & Mean & Max. \\
& & & & $95 \%$ CI & & $95 \%$ CI \\
\hline Observed data & 8.0 & 25.1 & 40.0 & 29.3 & 37.5 & 45.8 \\
Corrected data & 7.3 & 24.1 & 38.7 & 28.2 & 36.2 & 44.3 \\
\hline
\end{tabular}

who raised 47 female green turtles in captivity until after first reproduction. This hypothesis is also supported by Hatase et al. (2002) who conducted an isotope and telemetry study and found that immature turtles that migrate to coastal waters at a small size grow larger by feeding on nutrient-rich prey, such as benthos, until they reach sexual maturity. In contrast, immature turtles that stay in the pelagic zone for a longer period are smaller because of the scarcity of nutrient-rich prey in this habitat. Additionally, Bjorndal et al. (2003) determined that compensatory growth occurs in juvenile turtles but decreases as the turtles gain control over their movements.

Even though mutilation tagging is a labour-intensive method that takes a long time to produce results, we suggest that it (or DNA sampling) is the only way to ultimately determine the turnover rate of a population. In conclusion, the older age at first reproduction highlights the vulnerability of sea turtles as it has a negative effect on population replacement. Thus, with growing anthropogenic stresses the sustainability of turtle populations will become increasingly difficult (Scott et al. 2012).

Table 3. Summary of growth studies on age and size at first reproduction of loggerhead turtles. CMR: capture-mark-recapture; SC: skeletochronology; LFA: length-frequency-analysis; MT: mutilation tagging, i. e. notching; SSGR: notching or size-specific growth rates; SCL: straight carapace length: CCL: curved carapace length. $\mathrm{SCL}_{\mathrm{n}-\mathrm{t}}$ and $\mathrm{CCL}_{\mathrm{n}-\mathrm{t}}$ are measured from notch to tip; $\mathrm{SCL}_{\min }$ and $\mathrm{CCL}_{\min }$ are measured from the anterior point at midline (nuctual scute) to the posterior notch at midline between the supracaudals (Bolten 1999)

\begin{tabular}{|c|c|c|c|c|}
\hline Method & Age (yr) & Size $(\mathrm{cm})$ & Location & Source \\
\hline CMR & $30+$ & - & Australia & Limpus (1979) \\
\hline CMR & $10-15$ & 75.0 SCL $\mathrm{SC}_{\mathrm{n}-\mathrm{t}}$ & Florida & Mendonca (1981) \\
\hline CMR & 30 & 92.22 SCL & Florida & Frazer \& Ehrhart (1985) \\
\hline CMR & $16-28$ & $66.5-84.7 \mathrm{CCL}_{\mathrm{n}-\mathrm{t}}$ & Mediterranean & Casale et al. (2009b) \\
\hline $\mathrm{SC}$ & 22 & $92.5 \mathrm{SCL}$ & Chesapeake Bay & Klinger \& Musick (1995) \\
\hline $\mathrm{SC}$ & $20-24$ & $92.4 \mathrm{SCL}$ & Georgia & Parham and Zug (1997) \\
\hline $\mathrm{SC}$ & $14.9-28.5$ & 66.5-84.7 CCL $\mathrm{L}_{\mathrm{n}-\mathrm{t}}$ & Mediterranean & Casale et al. (2011a) \\
\hline $\mathrm{SC}$ & 24 & 69 & Mediterranean & Piovano et al. (2011) \\
\hline LFA & 26.5 & $87 \mathrm{CCL}_{\mathrm{n}-\mathrm{t}}$ & Southeast USA & Bjorndal et al. (2001) \\
\hline LFA & $23.5-29.3$ & $80 \mathrm{CCL}_{n-t}$ & Mediterranean & Casale et al. (2011b) \\
\hline MT & 19.5 & $72.8-98.5 \mathrm{SCL}_{\min }$ & South Africa & Baldwin et al. (2003) \\
\hline MT & 29 & $95.7-95.76 \mathrm{CCL}_{\min }{ }^{\mathrm{a}}$ & Australia & Limpus (2008) \\
\hline MT & $36.2^{\mathrm{b}}$ & $83.7 \mathrm{SCL}_{\min }{ }^{\mathrm{c}}$ & South Africa & This study \\
\hline SSGR & 45.0 & 98.2 CCL & Pacific and Atlantic & Scott et al. (2012) \\
\hline
\end{tabular}


Acknowledgements. We express our gratitude to Ezemvelo KZN Wildlife, which provided all of the information on nesting females, and to the reviewers and Dr. T. Petney for their suggestions for improving the manuscript.

\section{LITERATURE CITED}

Balazs GH, Chaloupka M (2004) Spatial and temporal variability in somatic growth of green sea turtles (Chelonia mydas) resident in the Hawaiian Archipelago. Mar Biol 145:1043-1059

Baldwin R, Hughes GR, Prince RIT (2003) Loggerhead turtles in the Indian Ocean. In: Bolten $A B$, Witherington $B E$ (eds) Loggerhead sea turtles I. Smithsonian Institution, Washington, DC, p 218-232

Bell CDL, Parsons J (2002) Cayman turtle farm head-starting project yields tangible success. Mar Turtle Newsl 98:5-6

Berner D, Blanckenhorn WU (2007) An ontogenetic perspective on the relationship between age and size at maturity. Funct Ecol 21:505-512

Bjorndal KA, Bolten AB, Koike B, Schroeder BA, Shaver DJ, Teas WG, Witzell WN (2001) Somatic growth function for immature loggerhead sea turtles, Caretta caretta, in southeastern U.S. waters. Fish Bull 99:240-246

Bjorndal KA, Bolten AB, Dellinger T, Delgado C, Martins HR (2003) Compensatory growth in oceanic loggerhead sea turtles: response to a stochastic environment. Ecology 84: 1237-1249

Bjorndal KA, Parsons J, Mustin W, Bolten AB (2012) Threshold to maturity in a long-lived reptile: interactions of age, size, and growth. Mar Biol 160:607-616

Bolten AB (1999) Techniques for measuring sea turtles. In: Eckert KL, Bjorndal KA, Abreu-Grobois FA, Donnelly M (eds) Research and management techniques for the conservation of sea turtles. IUCN/SSC Marine Turtle Specialist Group, Washington, DC, p 110-114

Bresette M, Gorham J (2001) Growth rates of juvenile green turtles (Chelonia mydas) from the Atlantic coastal waters of St. Lucie County, Florida, USA. Mar Turtle Newsl 91: $5-6$

Burnham KP, Anderson DR (2002) Model selection and multimodel inference: a practical information-theoretic approach. Springer, New York, NY

Casale P, Freggi D, Basso R, Vallini C, Argano R (2007) A model of area fidelity, nomadism, and distribution patterns of loggerhead sea turtles (Caretta caretta) in the Mediterranean Sea. Mar Biol 152:1039-1049

Casale P, d'Astore PP, Argano R (2009a) Age at size and growth rates of early juvenile loggerhead sea turtles (Caretta caretta) in the Mediterranean based on length frequency analysis. Herpetol J 19:29-33

> Casale P, Mazaris AD, Freggi D, Vallini C, Argano R (2009b) Growth rates and age at adult size of loggerhead sea turtles (Caretta caretta) in the Mediterranean Sea, estimated through capture-mark-recapture records. Sci Mar 73: 589-595

> Casale P, Conte N, Freggi D, Cioni C, Argano R (2011a) Age and growth determination by skeletochronology in loggerhead sea turtles (Caretta caretta) from the Mediterranean Sea. Sci Mar 75:197-203

Casale P, Mazaris AD, Freggi D (2011b) Estimation of age at maturity of loggerhead sea turtles Caretta caretta in the Mediterranean using length-frequency data. Endang Species Res 13:123-129
Chaloupka MY, Limpus CJ (1997) Robust statistical modelling of hawksbill sea turtle growth rates (southern Great Barrier Reef). Mar Ecol Prog Ser 146:1-8

> Chaloupka M, Limpus C, Miller J (2004) Green turtle somatic growth dynamics in a spatially disjunct Great Barrier Reef metapopulation. Coral Reefs 23:325-335

> Dutton DL, Dutton PH, Chaloupka M, Boulon RH (2005) Increase of a Caribbean leatherback turtle Dermochelys coriacea nesting population linked to long-term nest protection. Biol Conserv 126:186-194

Frazer NB, Ehrhart LM (1985) Preliminary growth models for green, Chelonia mydas, and loggerhead, Caretta caretta, turtles in the wild. Copeia 1985:73-79

Gupta RP (1973) Maximum likelihood estimate of the parameters of a truncated inverse Gaussian distribution. Metrika 20:51-53

Hatase H, Takai N, Matsuzawa Y, Sakamoto W and others (2002) Size-related differences in feeding habitat use of adult female loggerhead turtles Caretta caretta around Japan determined by stable isotope analyses and satellite telemetry. Mar Ecol Prog Ser 233:273-281

Hatase H, Matsuzawa Y, Sato K, Bando T, Goto K (2004) Remigration and growth of loggerhead turtles (Caretta caretta) nesting on Senri Beach in Minabe, Japan: lifehistory polymorphism in a sea turtle population. Mar Biol 144:807-811

Heppell SS, Snover ML, Crowder LB (2003) Sea turtle population ecology. In: Lutz PL, Musick JA, Wyneken J (eds) The biology of sea turtles. CRC Press, Boca Raton, FL, p 275-306

Hughes GR (1974) The sea turtles of south-east Africa II. The biology of the Tongaland loggerhead turtle Caretta caretta L. with comments on the leatherback turtle Dermochelys coriacea L. and the green turtle Chelonia mydas L. in the study region. Investigational Report 36, Oceanographic Research Institute, Durban

Hughes GR (2002) Ezemvelo KwaZulu-Natal Wildlife annual research report: The Tongaland sea turtle project 1 April 2001 - 31 March 2002. Ezemvelo KZN Wildlife, Pietermeritzburg

Hughes GR, Brent B (1972) The marine turtles of Tongaland, 7. The Lammergeyer 3:40-62

Hughes GR, Bass AJ, Mentis MT (1967) Further studies on marine turtles in Tongaland I. Lammergeyer 3:5-54

Klinger RC, Musick JA (1995) Age and growth of loggerhead turtles (Caretta caretta) from Chesapeake Bay. Copeia 1995:204-209

> Koch V, Brooks LB, Nichols WJ (2007) Population ecology of the green/black turtle (Chelonia mydas) in Bahía Magdalena, Mexico. Mar Biol 153:35-46

Limpus CJ (1979) Notes on growth rates of wild turtles. Mar Turtle Newsl 10:3-5

Limpus CJ (2008) A biological review of Australian marine turtles. 1. Loggerhead turtle Caretta caretta (Linneaus). Environmental Protection Agency, Queensland

> Limpus C, Chaloupka M (1997) Nonparametric regression modelling of green sea turtle growth rates (southern Great Barrier Reef). Mar Ecol Prog Ser 149:23-34

Limpus CJ, Couper PJ, Read MA (1994) The loggerhead turtle, Caretta caretta, in Queensland: population structure in a warm temperate feeding area. Mem Queensl Mus 37:195-204

Mendonca MT (1981) Comparative growth rates of wild immature Chelonia mydas and Caretta caretta in Florida. J Herpetol 15:447-451 
Molles MC (2010) Life histories. In: Molles MC (ed) Ecology: concepts and applications. McGraw-Hill, New York, NY, p 279-299

Musick JA, Limpus CJ (1997) Habitat utilization and migration in juvenile sea turtles. In: Lutz PL, Musick JA (eds) Biology of sea turtles. CRC Press, Boca Raton, FL, p 137-163

Nel R, Punt AE, Hughes GR (2013) Are coastal protected areas always effective in achieving population recovery for nesting sea turtles? PLoS ONE 8:e63525

Parham JF, Zug GR (1997) Age and growth of loggerhead sea turtles (Caretta caretta) of coastal Georgia: an assessment of skeletochronological age-estimates. Bull Mar Sci 61:287-304

Parker GH (1929) The growth of the loggerhead turtle. Am Nat 63:367-373

Piovano S, Clusa M, Carreras C, Giacoma C, Pascual M, Cardona L (2011) Different growth rates between loggerhead sea turtles (Caretta caretta) of Mediterranean and Atlantic origin in the Mediterranean Sea. Mar Biol 158: 2577-2587

R Core Team (2012) R: A language and environment for statistical computing. R Foundation for Statistical Comput-

Editorial responsibility: Jeffrey Seminoff,

La Jolla, California, USA ing, Vienna

Scott R, Marsh R, Hays GC (2012) Life in the really slow lane: loggerhead sea turtles mature late relative to other reptiles. Funct Ecol 26:227-235

Seminoff JA, Resendiz A, Nichols WJ, Jones TT (2002) Growth rates of wild green turtles (Chelonia mydas) at a temperate foraging area in the Gulf of California, México. Copeia 2002:610-617

Snover ML, Avens L, Hohn AA (2007) Back-calculating length from skeletal growth marks in loggerhead sea turtles Caretta caretta. Endang Species Res 3:95-104

Thorson JT, Punt AE, Nel R (2012) Evaluating population recovery for sea turtles under nesting beach protection while accounting for nesting behaviours and changes in availability. J Appl Ecol 49:601-610

Van Dam RP (1999) Measuring sea turtle growth. In: Eckert KL, Bjondal KA, Abreu-Grobois FA, Donnelly M (eds) Research and management techniques for the conservation of sea turtles. IUCN/SSC Marine Turtle Specialist Group, Washington, DC, p 149-151

West GB, Brown JH, Enquist BJ (2004) Growth models based on first principles or phenomenology? Funct Ecol 18:188-196

Submitted: May 23, 2012; Accepted: October 23, 2013

Proofs received from author(s): January 27, 2014 